\title{
COMPARISON BETWEEN SPATIAL DISTRIBUTION OF SECOND HOME PHENOMENON AND OTHER LEISURE MOBILITY FORMS IN KOPRIVNICA-KRIŽEVCI COUNTY
}

\author{
Petar Fijačko ${ }^{42}$ \\ Vuk Tvrtko Opačic ${ }^{43}$
}

\begin{abstract}
Unlike other forms of leisure spatial mobility (tourism, excursions, outdoor recreation), the second home phenomenon includes elements of habitation or place attachment to the receiving area. Although all leisure activities are generated by the desire for temporarily change of the dwelling place and escape to recreational amenity rich areas, the leading second home and tourism-excursion-outdoor recreation areas do not fully coincide. The goal of the paper is to examine the spatial overlapping of the second home phenomenon and other leisure mobility forms in Koprivnica-Križevci County to provide scientific contribution to the research of spatial (non)matching of the mentioned phenomena in rural areas of Croatia. Koprivnica-Križevci County was therefore chosen because it is a typical rural area in the Peripannonian region of Croatia, which does not stand out on a national level either according to a large number of second homes, or according to more prominent tourism flow, but in the near future a stronger development of leisure spatial mobilities can be expected.

The spatial overlapping of the second home phenomenon and other leisure mobility forms in Koprivnica-Križevci County was examined through the following steps: a) identification of the leading second home areas in the County according to the number of second homes at the level of the settlement in 2011; b) identification of leading tourism-excursion-outdoor recreation areas in the County at the level of the settlement according to four indicators: number of overnights in 2016, number of tourist beds in 2016, number of catering facilities linked with tourismexcursions-outdoor recreation in 2017, number of tourist attractions in 2017; and c) analysis of spatial overlapping of second home phenomenon and other leisure mobility forms.
\end{abstract}

Key words: second home phenomenon, tourism, excursions, recreation, Koprivnica-Križevci County, Croatia

\section{INTRODUCTION}

All leisure activities are generated by the desire for temporarily change of the dwelling place and escape to recreational amenity rich areas. Thus, second home phenomenon, as a specific form of spatial mobility initiated by the consumption, combine several aspects of mobilities with regard to their temporality and spatiality, for example: a) oneday visits to the second home after work (day excursions), b) stays in second homes on weekends and during short holidays, c) stays for longer holidays (seasonal migrations), d) stays in the majority of the year, which can be transformed into e) permanent

\footnotetext{
${ }^{42}$ MS, Koprivnica Tourist Board, Trg bana Josipa Jelačića 7, 48000 Koprivnica, Croatia.

${ }^{43}$ Associate Professor, University of Zagreb, Faculty of Science, Department of Geography, Marulićev trg 19/II, 10000 Zagreb, Croatia.
} 
migrations of retired second home owners, but also of other owner profiles (Williams et al., 2004).

Unlike other forms of leisure spatial mobility (tourism, excursions, outdoor recreation), the second home mobilities include residential elements or place attachment elements to the receiving area, as well as leisure mobility elements. Considering the level of attachment to a receiving area, second home owners belong to a category in between the tourist or excursionist that symbolizes mobility, and the local recreationist (permanent resident of the nearby area) characterized by the strongest place attachment. Although all forms of leisure spatial mobility are basically motivated by the same or similar reasons, they differ between themselves and therefore their spatial distribution does not always coincide. Generally, non-matching of the spatial distribution of second home phenomenon and other forms of leisure spatial mobility are more prominent in the leading mass tourism regions (e.g. seaside or ski tourist resorts) (Opačić and Mikačić, 2009), than in rural areas away of mass tourism demand. However, in rural areas at the local level, differences in spatial overlapping of second home phenomenon and other forms of leisure spatial mobilities (tourism, excursions, outdoor recreation) can also be noticed, because the second home phenomenon is more dispersed (Opačić, 2009; Opačić, 2012; Miletić et al., 2017). Whereas, other forms of leisure spatial mobility are usually more concentrated around the most attractive locations for leisure activities in the countryside.

Analyses of the spatial overlapping of second home phenomenon and other leisure mobility forms is an introductory step in the research of the relationship between leisure mobility forms in rural areas of Croatia. Their complex linkages are difficult to analyze for rural areas of Croatia in whole. Therefore, they can be analyzed more precisely in a smaller area. Koprivnica-Križevci County was chosen as an illustrative case study because it is a typical rural area in the Peripannonian region of Croatia, which does not stand out on a national level either according to a large number of second homes (only 4,079 second homes or $1.64 \%$ of total number of second homes in Croatia according to Population Census data in 2011; Croatian Bureau of Statistics, 2013) or according to more prominent tourism flow (18,864 tourist arrivals in 2016 or $0.12 \%$ of total tourist arrivals in Croatia in 2016; Croatian Bureau of Statistics, 2017), but in the near future a stronger development of leisure spatial mobilities can be expected (Fig. 1). 


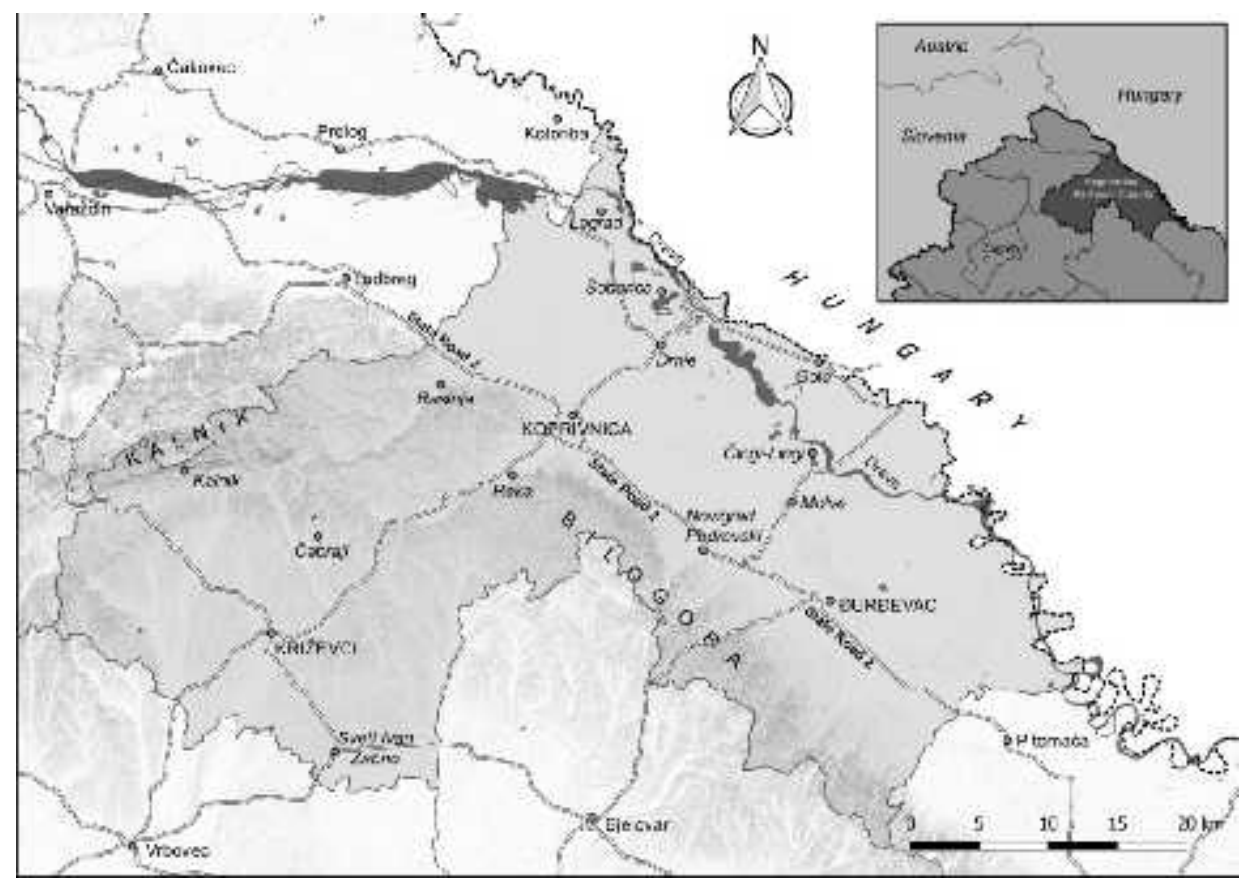

Fig. 1. Koprivnica-Križevci County

Sources: GISDATA d.o.o., 2005; State Geodetic Administration, 2005; State Geodetic Administration, 2015

Koprivnica-Križevci County is located at the contact of several physical-geographical spatial units. Along the Drava river, and state border to Hungary, a wide Podravina plain is stretching. It is the leading agricultural area in the County, with a dense network of rivers and streams that have formed numerous meanders and swampy areas in former river flows. To the west, the Podravina plain gradually exceeds into the forested slopes of the Bilogora and the Kalnik hills, whose southern parts are marked by vineyards in the cultural landscape (Dugački 1974; Feletar and Feletar, 2008; Magaš, 2013; Opačić and Fijačko, 2017). Most of the second home mobilities, as well as the tourismexcursion-outdoor recreation spatial mobilities towards the rural areas of KoprivnicaKriževci County are generated from the regional and subregional urban centers from the County (e.g. Koprivnica) as well as from neighboring counties (e.g. cities of Varaždin and Bjelovar) (Fijačko, 2016, Karaula, 2016 ).

\section{RESEARSCH GOAL AND METHODOLOGY}

The goal of the research is to examine the spatial overlapping of the second home phenomenon and other leisure mobility forms in Koprivnica-Križevci County to provide scientific contribution to the research of spatial (non)matching of the mentioned phenomena in rural areas of Croatia. The research has been based on the methodological instruments of geographical analysis and synthesis and includes 
analysis of statistical data (descriptive statistics), as well as visualization of spatial data in GIS program QGIS Desktop 2.18.11.

The spatial overlapping of the second home phenomenon and other leisure mobility forms in Koprivnica-Križevci County was examined through the following steps:

1) identification of the leading second home areas in the County according to the number of second homes at the level of the settlement in 2011(Croatian Bureau of Statistics, 2014);

2) identification of the leading tourism-excursion-outdoor recreation areas in the County at the level of the settlement in 2016 or 2017;

3) analysis of spatial overlapping of second home phenomenon and other leisure mobility forms.

Quantitative methods of classification in GIS (quartile, Jenks, geometrical interval, standard deviation) did not prove to be useful for this purpose; hence class boundaries in all steps were determined intentionally, in order to reflect differences in the intensity the second home phenomenon and other leisure mobility forms in Koprivnica-Križevci County.

For the purpose of identification of the leading second home areas in the County all settlements with at least one registered second home were grouped into one out of five classes assigned from 1 to 5 points according to the Census 2011 data (Croatian Bureau of Statistics, 2014) as follows: a) $\leq 10$ second homes $=1$ point, b) 10-50 second homes $=2$ points, c) $50-100$ second homes $=3$ points, d) 100-300 second homes $=4$ points, e) $>300$ second homes $=5$ points.

For identification of the leading tourism-excursion-outdoor recreation areas in the County, four individual indicators were used: a) number of overnights in 2016 (Koprivnica-Križevci County Tourist Board Internal Data, 2017), b) number of tourist beds in 2016 (Koprivnica-Križevci County Tourist Board Internal Data, 2017), c) number of catering facilities linked with tourism-excursions-outdoor recreation in 2017 (Kalnik Tourist Board Official Website, 2017; Koprivnica Tourist Board Official Website, 2017; Koprivnica-Križevci County Tourist Board Official Website, 2017; Križevci Tourist Board Official Website, 2017) and d) number of tourist attractions in 2017 (Kalnik Tourist Board Official Website, 2017; Koprivnica Tourist Board Official Website, 2017; Koprivnica-Križevci County Tourist Board Official Website, 2017; Križevci Tourist Board Official Website, 2017). Each indicator in each settlement was assigned according to the criteria in Table 1. The higher points were scored to classes with higher value and lower points to classes with lower value. By counting points for all four individual indicators, an integrated indicator for the total presence of other forms of leisure activities was obtained for each settlement whereupon all settlements were classified into 5 classes assigned from 1 to 5 points. 
Tab. 1. Indicators and assignment values used for identification of the leading tourismexcursion-outdoor recreation areas in Koprivnica-Križevci County

\begin{tabular}{|l|c|c|c|c|c|}
\hline \multirow{2}{*}{\multicolumn{1}{|c|}{ INDICATOR }} & \multicolumn{5}{|c|}{ POINTS } \\
\cline { 2 - 6 } & $\mathbf{1}$ & $\mathbf{2}$ & $\mathbf{3}$ & $\mathbf{4}$ & $\mathbf{5}$ \\
\hline $\begin{array}{l}\text { Number of overnights } \\
(2016)\end{array}$ & $\leq 100$ & $100-500$ & $500-1,000$ & $\begin{array}{c}1,000- \\
10,000\end{array}$ & $>10,000$ \\
\hline $\begin{array}{l}\text { Number of tourist beds } \\
(2016)\end{array}$ & $\leq 10$ & $10-20$ & $20-50$ & $50-100$ & $>100$ \\
\hline $\begin{array}{l}\text { Number of catering } \\
\text { facilities linked with } \\
\text { tourism-excursions- } \\
\text { outdoor recreation } \\
\text { (2017) }\end{array}$ & $1-2$ & $3-4$ & $5-9$ & $\geq 10$ & \\
\hline $\begin{array}{l}\text { Number of tourist } \\
\text { attractions (2017) }\end{array}$ & $1-2$ & $3-4$ & $\geq 5$ & & $\geq 10$ \\
\hline $\begin{array}{l}\text { Integrated indicator for } \\
\text { the total presence of } \\
\text { other forms of leisure } \\
\text { activities }\end{array}$ & $\mathbf{1}$ & $\mathbf{2 - 3}$ & $\mathbf{4 - 5}$ & $\mathbf{6 - 9}$ & $\geq 10$ \\
\hline
\end{tabular}

In the analysis of spatial overlapping of second home phenomenon and other leisure mobility forms, for each settlement in the County level of overlapping of both indicators (number of second homes scored 1-5 points, number of points 1-5 for total presence of other forms of leisure activities) was identified and scored 1-5 afterwards all settlements were classified into 5 classes as follows:

a) no overlapping - one of two analyzed indicators is not registered in settlements of this class;

b) weak overlapping - point difference between two analyzed indicators is 3 or 4 ;

c) moderate overlapping - point difference between two analyzed indicators is 2 ;

d) strong overlapping - point difference between two analyzed indicators is 1;

\footnotetext{
${ }^{44}$ Only catering facilities included into tourism supply on official web pages of tourist boards of the County or Towns/Municipalities were taken into analysis (Kalnik Tourist Board Official Website, 2017; Koprivnica Tourist Board Official Website, 2017; Koprivnica-Križevci County Tourist Board Official Website, 2017; Križevci Tourist Board Official Website, 2017).

${ }_{45}$ All settlements with at least one attraction in tourism-excursion-outdoor recreation supply (according to official tourist boards of the County or Towns/Municipalities (Kalnik Tourist Board Official Website, 2017; Koprivnica Tourist Board Official Website, 2017; KoprivnicaKriževci County Tourist Board Official Website, 2017; Križevci Tourist Board Official Website, 2017) were taken into analysis. Attractions taken into account can be classified into following groups: nature attractions, museums/galleries, wineries, events, popular fishing areas, popular excursion areas.
} 
e) complete overlapping - without point difference between two analyzed indicators.

\section{IDENTIFICATION OF THE LEADING SECOND HOME AREAS IN KOPRIVNICA-KRIŽEVCI COUNTY}

According to Population Census 2011 data, in Koprivnica-Križevci County second homes were registered in 169 out of 264 settlements (Croatian Bureau of Statistics, 2013). Based on the above described methodology, settlements with the appearance of second homes were classified in 5 classes (Fig. 2).

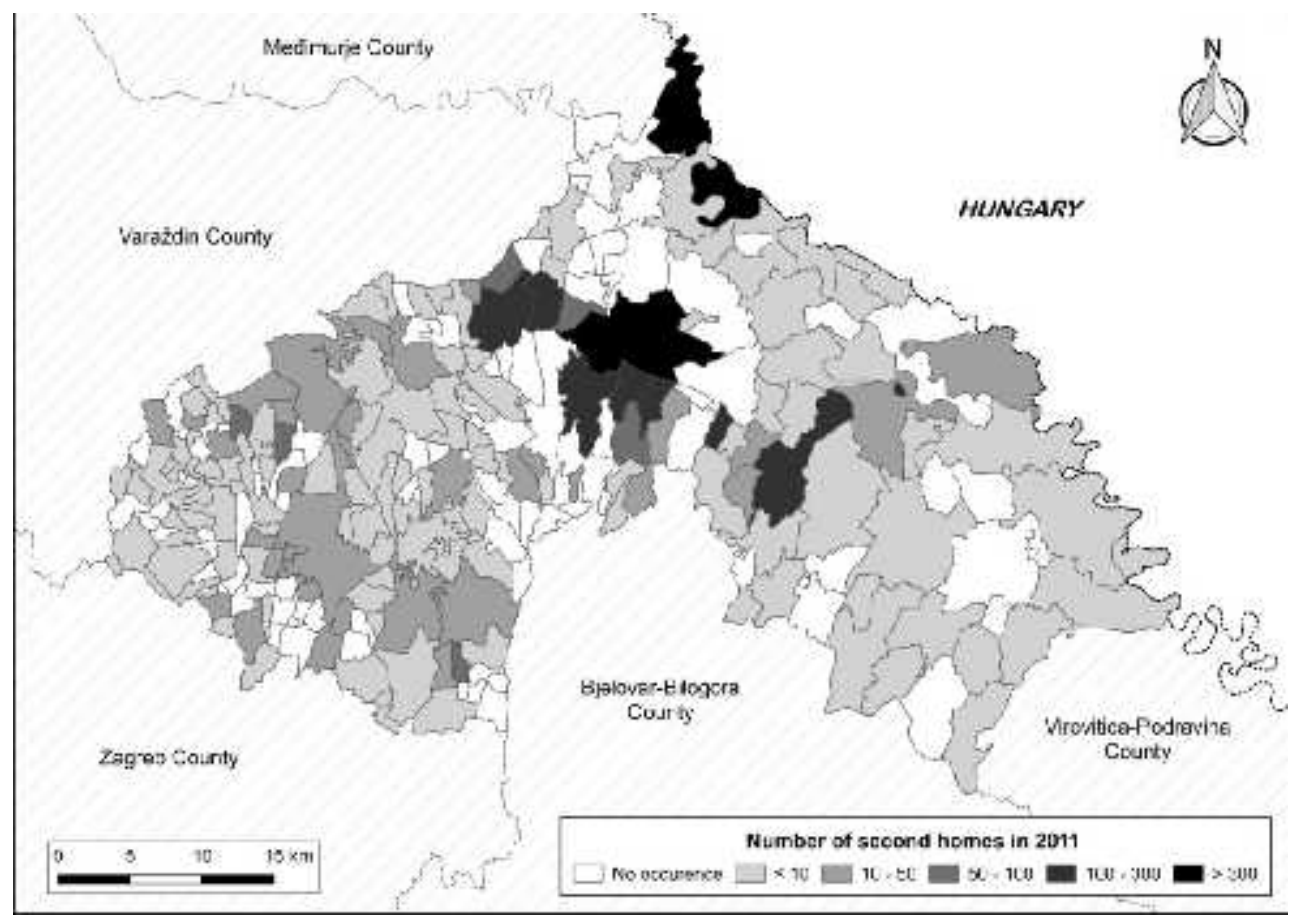

Fig. 2. Number of second homes in settlements of Koprivnica-Križevci County 2011

Sources: Croatian Bureau of Statistics, 2014; State Geodetic Administration, 2005 The only two settlements in Koprivnica-Križevci County in the top class, with more than 300 second homes in 2011 were Koprivnica (802 second homes) and Legrad (384). Most of second homes registered in Koprivnica are located within the area of local council of Vinica authority, situated between the flat part of the city and slopes of the Bilogora hills. That points to the fact that the majority of second homes are located in the outskirts of the city and in its rural recreational countryside. In the administrative borders of the settlement of Legrad there is the most developed second home resort in Koprivnica-Križevci County - the Šoderica lake. Šoderica is a typical second home resort that has been spontaneously developed along the artificial lake built for the extraction of gravel for construction purposes (Feletar, D., 2016, Feletar, P. 2016 
Fijačko, 2016). It is the leading second home resort in the County and the only one settlement that is continuously from 1971-2011 in top five settlements according to the number of second homes. In 1971 and 1981 Šoderica was the leading second home resort in the County, while in 1991, 2001 and 2011 it was on the second place according to the number of second homes (Opačić and Fijačko, 2017, 101).

Eight settlements were classified in the second class with 100-300 second homes: Starigrad, Subotica Podravska, Borovljani, Reka, Novigrad Podravski, Čingi-Lingi and Rasinja. The majority of the second homes in these settlements is purposefully erected at the suitable locations on the contact of the Podravina plain and the Bilogora hills in the rural recreational countryside of Koprivnica. Most of the settlements listed above are situated along or near "the Podravina Highway" (state road No. 2). The exception is the village of Čingi-Lingi, another typical second home resort spontaneously formed on the shores of the artificial lake in the Podravina plain.

Six settlements in the "50-100 second homes class" are located on two distinct locations: a) near Koprivnica, at the contact of the Podravina plain and northern slopes of the Bilogora hills (Cvetkovec, Kunovec Breg, Jagnjedovec) and b) in the Kalnik hills area (Šopron, Črnčevec). The only exception is Brdo Cirkvensko on the southern slopes of the Bilogora hills. Second homes in these settlements were mostly purposefully built by their owners.

In the "10-50 second homes class", 36 settlements were identified, primarily in the Kalnik hills, but also in other locations of the County (e.g. slopes of the Bilogora hills, the Podravina plain). In the settlements of this class, two main ways in the genesis of second home phenomenon have been noticed: a) purposefully construction of second homes by their owners, and b) conversion and adaptation of former houses for permanent residence into second homes after the death of the older generation. Latter particularly appears in scattered settlements in the Kalnik and Bilogora hills, which were early affected by the emigration of the younger population (Opačić and Fijačko, 2017, 113).

In the bottom class with 1-10 second homes, 117 settlements were classified. Those settlements can be found in different parts of the County, so the regularity in their spatial distribution could not be recognized. In this group of settlements, the second home phenomenon is a random occurrence, and it usually arises from conversion of former houses for primary housing into the houses for secondary housing after the death of older family members.

As the leading second home areas in Koprivnica-Križevci County can be recognized: a) second home resorts Šoderica and Čingi-Lingi on artificial lakes in the Drava river floodplain, b) slopes, especially northern ones, of the Bilogora hills and southern slopes of the Kalnik hills, as well as c) the city of Koprivnica together with certain settlements in its rural recreational countryside, particularly near "the Podravina Highway" (state road No. 2). 


\section{IDENTIFICATION OF THE LEADING TOURISM-EXCURSION-OUTDOOR RECREATION AREAS IN KOPRIVNICA-KRIŽEVCI COUNTY}

According to the earlier clarified methodology, and based on the level of development of accommodation, catering and tourist attractions supply of all settlements in Koprivnica-Križevci County, each settlement was assigned points for the total presence of other forms of leisure activities (tourism, excursion, outdoor recreation) (Fig. 3). It should be pointed out that from the total of 264 settlements in the County, appearance of other forms of leisure activities was registered in only 58 settlements.

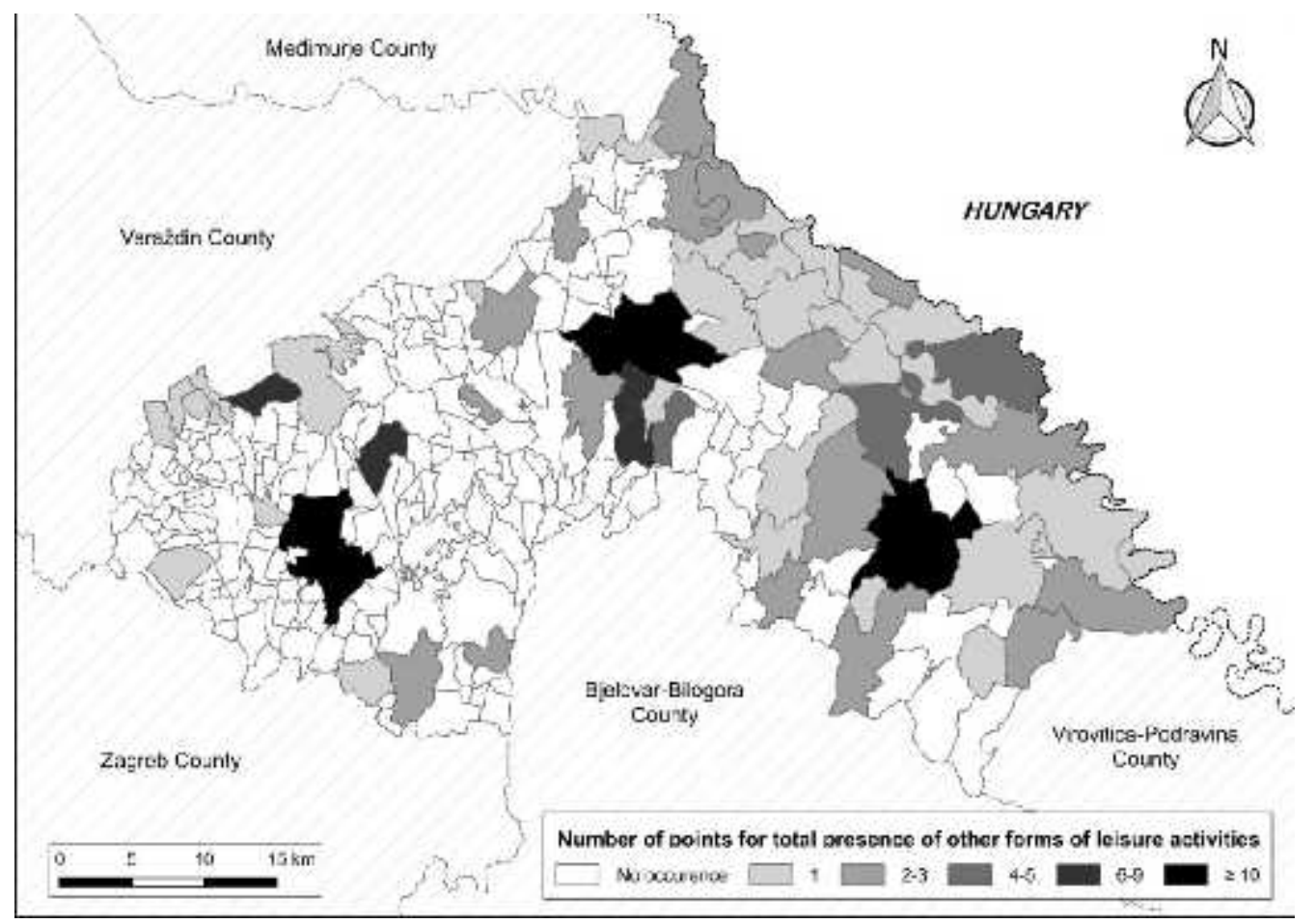

Fig. 3. Other forms of leisure activities in settlements of Koprivnica-Križevci County Sources: Kalnik Tourist Board Official Website, 2017; Koprivnica Tourist Board Official Website, 2017; Koprivnica-Križevci County Tourist Board Internal Data, 2017; Koprivnica-Križevci County Tourist Board Official Website, 2017; Križevci Tourist Board Official Website, 2017; State Geodetic Administration, 2005

Most points for the total presence of other forms of leisure activities were assigned to urban settlements - Koprivnica (17 points), Križevci (16) and Đurđevac (15). Koprivnica has about 200 registered tourist beds, approximately 20,000 overnights, 15 catering facilities linked with tourism-excursions-outdoor recreation, two museums ("Museum of Koprivnica", "Food Museum Podravka"), one gallery, two big events - 
"Motives of Podravina", "Renaissance Festival", 46 and one protected area of nature ("Old Sweet Chestnut Tree in the Močile Area" - monument of nature), and therefore lead the category of urban settlements. Križevci has a few registered tourist beds more, but four time less overnights, dozens of catering facilities and three protected areas of nature ("Župetnica Forest", "The Park near the Vladimir Nazor Primary School in Križevci" - monument of park architecture, "The Park near Agricultural School in Križevci" - monument of park architecture), two museums ("Museum of Križevci", "Library and Small Museum of Greek-Catholic Diocese"), one gallery, few wineries and one big event - "Križevačko veliko spravišče". Đurđevac also has about 200 registered tourist beds, 15,000 overnights, while lower number of catering facilities linked with tourism-excursions-outdoor recreation (3) is partly compensated by relatively diverse tourist attractions supply which consists of "Đurđevac Sands" special geographical and botanical reserve, museum/gallery/interpretation center placed in the fort of "Old Town Đurđevac", several wineries, excursion sites, fishing area and event called "Picokijada".

Generally, cultural heritage is often concentrated in urban areas (Pančić Kombol, 2006). Towns or cities are usually centers of sacral, secular and other architectural buildings often gathered into old town cores of great cultural value. Also, urban settlements are areas of more developed functions and greater possibilities for leisure activities, so it is obvious that these areas are leaders in accommodation, catering and tourist attractions supply in Koprivnica-Križevci County.

Settlements with 6-9 points for the total presence of other forms of leisure activities are settlements in the outskirts of Koprivnica - Jagnjedovec (7) and Starigrad (6). Those settlements have smaller number of accommodation capacities, but stand out by quality catering facilities (e.g. "Podravska klet") and excursion sites ("Sunny Village", "Podravka Recreation Center") which are common attractive locations for visitors, mostly residents of the nearby Koprivnica. In the same class are also the following settlements: Kalnik (9) and Čabraji (6). In Čabraji, there is a fishing area and an excursion site. Kalnik, on the other hand, is significant natural landscape and wellknown hiking destination. That confirms the hypothesis that vertical relief dissection is one of the most important natural recreational attractions (Halseth, 2004).

Following by the number of assigned points for the total presence of other forms of leisure activities (4-5) are settlements Bakovčica (5), Ždala (5) and Molve (4). To their classification, together with the existence of certain accommodation capacities, also contributed presence of excursion sites (Jastrebov vrh - Bakovčica), galleries ("Gallery Tomo Balažin" in Bakovčica, "Gallery Mijo Kovačić" and "Gallery Molve painters

\footnotetext{
${ }^{46}$ Historical-tourism event "Renaissance Festival" in Koprivnica gathers more than 1,000 participants from dozen of European countries and attracts about 45,000 visitors during the four days (Koprivnica Tourist Board Official Website, 2017). It was declared as a top event of Croatia and assigned Superbrands status (Koprivnica Tourist Board Official Website, 2017).
} 
circle" in Molve) and/or attractive natural sites (e.g. Čambina near Ždala) gathered under the protected natural area of the Regional park Mura-Drava.

The Regional park Mura-Drava is the main reason for assigning points for the total presence of other forms of leisure activities to most of the settlements from the "1-3 points class", and especially to the following settlements: Botovo, Đelekovec, Gola, Legrad, Čingi-Lingi, Novo Virje, Podravske Sesvete. Preserved natural forest vegetation and vicinity of protected areas are important natural recreational amenities (Opačić, 2010; 2011), to which the presence of water-based attractions should be added - the Drava river, as well as artificial lakes in the Drava river floodplain (Šoderica, Čingi-Lingi). Areas with plenty of forest and water amenities are the most attractive for recreation. Presence of water is considered as a basic precondition for outdoor recreation, either as a source where recreational activities are being held on, or as an attractive landscape element (Pigram and Jenkins, 1999; Cooper, 2006; Poni y, 2010).

Other settlements which were assigned 1-3 points for total presence of other forms of leisure activities are primarily situated on the slopes of the Kalnik hills and the Bilogora hills (settlement Rasinja), as well as in the surroundings of Koprivnica (settlement Reka) and Đurđevac (settlements Virje, Hampovica, Čepelovac), near "the Podravina Highway" (state road No. 2).

As the leading tourism-excursion-outdoor recreation areas in Koprivnica-Križevci County can be recognized: a) urban settlements: Koprivnica $(23,955$ inhabitants in 2011; Croatian Bureau of Statistics, 2013), Križevci (11,231 inhabitants in 2011), Đurđevac (6,349 inhabitants in 2011), b) certain settlements in the Drava river floodplain and c) several settlements in the vicinity of Koprivnica and Đurđevac near "the Podravina Highway" (state road No. 2).

\section{ANALYSIS OF SPATIAL OVERLAPPING OF SECOND HOME PHENOMENON AND OTHER FORMS OF LEISURE SPATIAL MOBILITIES IN KOPRIVNICA-KRIŽEVCI COUNTY}

In 85 of 264 settlements in Koprivnica-Križevci County, presence of second home phenomenon or any other form of leisure spatial mobility has not been registered (Fig. 4). These are generally smaller rural settlements characterized by depopulation features. In 131 settlements, there is no overlapping because only one phenomenon has been registered, mostly second home phenomenon. ${ }^{47}$

\footnotetext{
${ }^{47}$ Number of second homes is somewhat higher in the following settlements without the presence of other leisure mobility forms: Subotica Podravska, Borovljani, Cvetkovec, Kunovec Breg, Šopron, Brdo Cirkvensko and Dedina.
} 


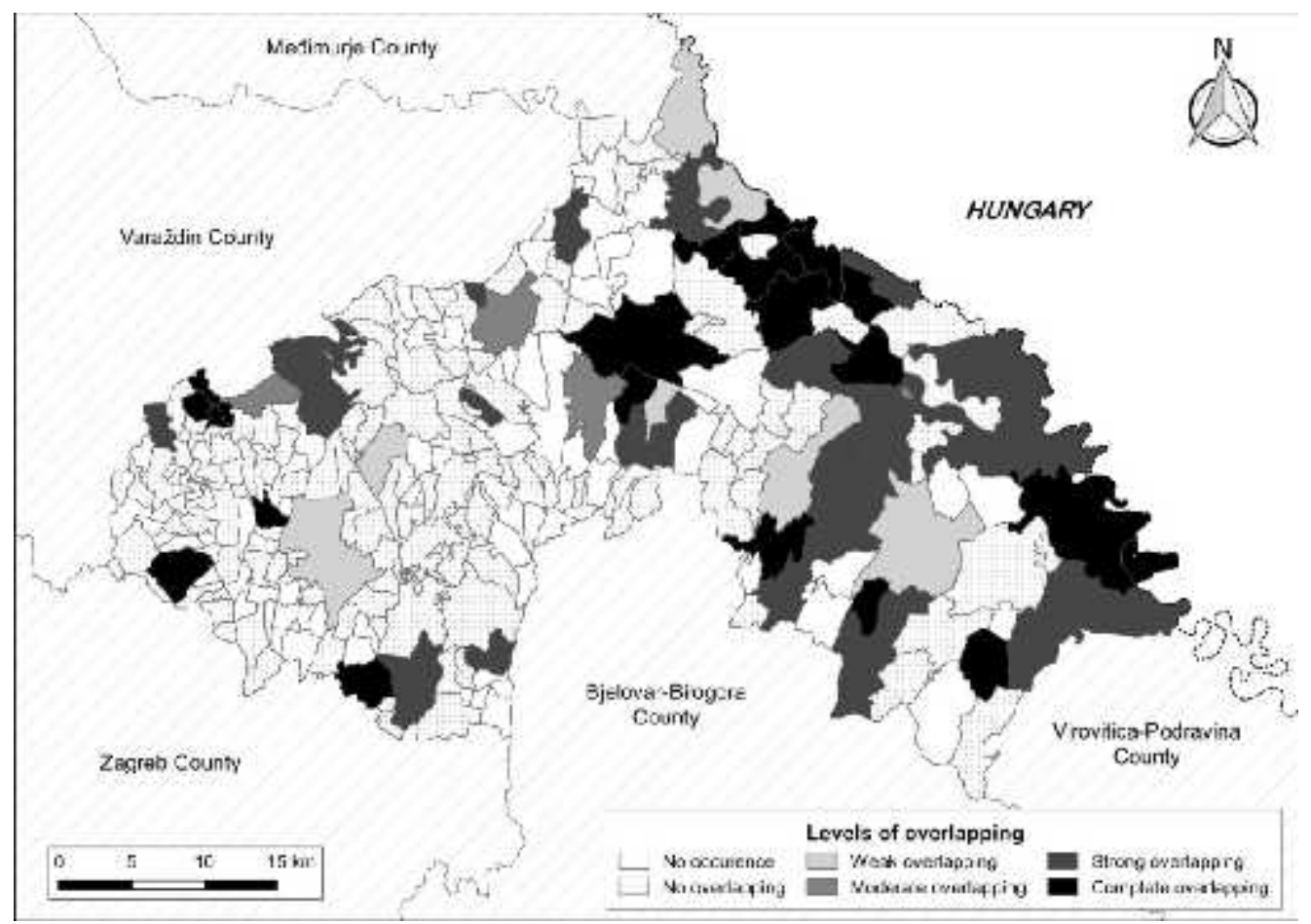

Fig. 4. Spatial overlapping of second home phenomenon and other forms of leisure spatial mobilities in settlements of Koprivnica-Križevci County

Sources: Croatian Bureau of Statistics, 2014; Kalnik Tourist Board Official Website, 2017; Koprivnica Tourist Board Official Website, 2017; Koprivnica-Križevci County Tourist Board Internal Data, 2017; Koprivnica-Križevci County Tourist Board Official

Website, 2017; Križevci Tourist Board Official Website, 2017; State Geodetic Administration, 2005

For the weak overlapping, it is characteristic that there is a large difference between the number of points assigned to each indicator. Therefore, in settlements Legrad, Draganovec and Novigrad Podravski, number of points for the presence of second home phenomenon is larger than the number of points for the presence of other forms of leisure activities. These settlements are typical second home resorts: part of the settlement Legrad is the most developed second home resort in Koprivnica-Križevci County - the Šoderica lake (Opačić and Fijačko, 2017), while settlements Draganovec and Novigrad Podravski are typical vineyard areas with significant concentration of second homes. Reverse situation is in the urban settlements Križevci and Đurđevac where other leisure mobility forms are more prominent due to the stronger function of primary housing, more diverse cultural tourism supply, and larger number of accommodation capacities and catering facilities. Beside those urban settlements, rural settlement Čabraji has to be mentioned. That settlement is also characterized by larger number of points for the presence of other leisure mobility forms than the number of points for the presence of second home phenomenon, but it should be emphasized that, 
in this case, the real reason for such a result is a small number of second homes in the observed area.

Moderate overlapping is registered in the settlements where the presence of one indicator is more prominent, but other indicator is also "strong" enough and its presence shouldn't be neglected. Specifically, settlement Čingi-Lingi is another lake resort where second home phenomenon traditionally prevails, but which has sufficient attractiveness for other forms of leisure activities too. Second home phenomenon is also more prominent in settlements Reka and Rasinja, but those settlements are suitable for other forms of leisure activities too, due to favorable traffic position and the vicinity of Koprivnica. This category also includes the settlement Kalnik, which is characterized by a reversed situation - as a hiking site and protected area of nature, Kalnik is more exposed to the other forms of leisure activities, especially excursion and outdoor recreation. However, attractiveness of such a landscape also creates desire to spend more time in such area and, accordingly, has influence on the development of the second home phenomenon.

Strong or complete overlapping is identified in settlements in the Drava river floodplain (Molve, Ždala, Podravske Sesvete, Hlebine, Gola, Đelekovec, Novo Virje, Sigetec, Torčec, Drnje, Ferdinandovac, Gotalovo, Brodić, Gabajeva Greda, Otočka). This is the area of Regional park Mura-Drava, which is, with all of its attractive components, the leading area in Koprivnica-Križevci County considering both indicators. Beside those settlements, strong or complete overlapping is registered in several settlements on the slopes of the Bilogora hills (Jagnjedovec, Bakovčica, Lukovec, Prnjavor Lepavinski) and the Kalnik hills (Osijek Vojakovački, Vojnovec Kalnički, Obrež Kalnički), as well as in settlements in the vicinity of Đurđevac (Čepelovac, Hampovica, Miholjanec, Mičetinac, Prugovac), near "the Podravina Highway" (state road No. 2). High level of overlapping is also noticeable in some settlements from the Križevci area (Gornja Rijeka, Cepidlak, Sveti Ivan Žabno, Kapela Ravenska, Guščerovec, Brezovljani), but this is the result of an equally small number of assigned points for both indicators.

However, the only representatively complete overlapping of second home phenomenon and other forms of leisure activities is registered in settlements Koprivnica and Starigrad, where the number of assigned points for both indicators is high or very high. Koprivnica, as the leading population and functional center of Koprivnica-Križevci County and relatively diverse area regarding relief, has developed supply and demand for both second home phenomenon and other forms of recreational activities. As a suburban settlement of Koprivnica, Starigrad is so closely connected with Koprivnica that they form a continuous urbanized area, so the observations from above can be partially transferred to this area as well. 


\section{CONCLUSION}

In general, the overlapping between spatial distribution of second home phenomenon and other leisure mobility forms in Koprivnica-Križevci County was identified. Second home resorts Šoderica and Čingi-Lingi on artificial lakes in the Drava river floodplain, slopes, especially northern ones, of the Bilogora hills and southern slopes of the Kalnik hills, as well as certain settlements in rural recreational countryside of the city of Koprivnica, particularly near "the Podravina Highway" (state road No. 2) were recognized as the leading second home areas in the County. Urban settlements: Koprivnica, Križevci, Đurđevac, certain settlements in the Drava river floodplain and several settlements in the vicinity of Koprivnica and Đurđevac near "the Podravina Highway" (state road No. 2) were recognized as the leading tourism-excursion-outdoor recreation areas in the County.

Though the leading second home areas in the County are at the same time the leading tourism-excursion-outdoor recreation areas, several exceptions were noticed. At the Kalnik hills and the Bilogora hills second home phenomenon is more prominent than the other leisure mobility forms (tourism, excursions, outdoor recreation). On the other hand, in towns of Križevci and Đurđevac the other leisure mobility forms (tourism, excursions, outdoor recreation) are more prominent than the second home phenomenon. Based on the research in Koprivnica-Križevci County, it can be concluded that in the rural second home areas the water-based attractions (e.g. artificial lakes and rivers) are equally attractive for the second home phenomenon and the other leisure mobility forms (tourism, excursions, outdoor recreation). The hilly areas are primarily characterized by the second home phenomenon, and in the following stage of the leisure activities development, rural tourism could be expected. In urban settlements (cities, towns) other leisure mobility forms (tourism, excursions, outdoor recreation) are more developed than the second home phenomenon, due the stronger function of primary housing, wider cultural tourism supply (events), as well as larger number of accommodation and catering facilities.

\section{ACKNOWLEDGEMENT}

This research was conducted within the short-term financial support of the University of Zagreb for 2016 "Comparative analysis of spatial development of secondary housing and tourism in Croatia". 


\section{REFERENCES}

1. Cooper, C. (2006). Lakes as tourism destination resources. In: Lake tourism (eds. Hall, C. M., Härkönen, T.). Channel View Publications, Clevedon, 27-42.

2. Croatian Bureau of Statistics (2013). Census of Population 2011, http://www.dzs.hr/, Zagreb (October 26 $6^{\text {th }}$ 2017)

3. Croatian Bureau of Statistics (2014). Census of Population 2011, internal data. Zagreb.

4. Croatian Bureau of Statistics (2017). Tourism in 2016. Zagreb.

5. Dugački, Z. (1974). Lonjsko-ilovska zavala $i$ bilogorska Podravina. In: Geografija SR Hrvatske - knjiga 2: Središnja Hrvatska (ed. Crkvenčić, I.). Školska knjiga, Zagreb.

6. Feletar, D. (2016). Geneza i eksploatacija šljunka i pijeska na području Šoderice. Podravina: časopis za multidisciplinarna istraživanja, 15 (29), 24-35.

7. Feletar, P. (2016). Geografski položaj i prometna povezanost jezera „Šoderica“. Podravina: časopis za multidisciplinarna istraživanja, 15 (29), 12 23.

8. Feletar, D., Feletar, P. (2008). Prirodna osnova kao čimbenik naseljenosti gornje hrvatske Podravine. Podravina: časopis za multidisciplinarna istraživanja, 7 (13), 167-212.

9. Fijačko, P. (2016). Struktura, obilježja i stavovi posjetitelja Šoderice 2015. godine. Podravina: časopis za multidisciplinarna istraživanja, 15 (29), 101-111.

10. GISDATA d.o.o. (2005). Digital atlas of the Republic of Croatia. Zagreb.

11. Halseth, G. (2004). The "cottage privilege": increasingly elite landscapes of second homes in Canada. In: Tourism, mobility and second homes: between elite landscape and common ground (eds. Hall, C. M., Müller, D. K.). Channel View Publications, Clevedon, 35-54.

12. Kalnik Tourist Board official website (2017). www.tz.kalnik.hr, (June $20^{\text {th }}$ 2017)

13. Karaula, Ž. (2016). „Bjelovarci“na Šoderici. Podravina: časopis za multidisciplinarna istraživanja, 15 (29), 52-57.

14. Koprivnica-Križevci County Tourist Board Internal Data (2017).

15. Koprivnica-Križevci County Tourist Board official website (2017). www.tzkoprivnicko-krizevacka.hr, (June 19 ${ }^{\text {th }}$ 2017)

16. Koprivnica Tourist Board official website (2017). www.koprivnicatourism.com, (June 17 ${ }^{\text {th }}$ 2017)

17. Križevci Tourist Board official website (2017). www.tz-krizevci.hr, (June 18 ${ }^{\text {th }}$ 2017)

18. Magaš, D. (2013). Geografija Hrvatske. Sveučilište u Zadru - Odjel za geografiju and Izdavačka kuća Meridijani, Zadar. 
19. Miletić, G.-M., Peračković, K., Marinović Golubić, M. (2017). Socio-spatial patterns of the contemporary second home phenomenon in Croatia. Društvena istraživanja, 26 (1), 79-100.

20. Opačić, V. T. (2009). Recent characteristics of the second home phenomenon in the Croatian littoral. Hrvatski geografski glasnik, 71 (1), 33-66.

21. Opačić, V. T. (2010). Motivation models for owning second homes on the Croatian littoral: The example of Malinska on the island of Krk. Acta Turistica Nova, 4 (1), 81-113.

22. Opačić, V. T. (2011). Prijedlog koncepta istraživanja vikendaštva u receptivnome vikendaškom području. Hrvatski geografski glasnik, 73 (1), 181200.

23. Opačić, V. T. (2012). Vikendaštvo u hrvatskom priobalju: jučer, danas, sutra. Hrvatska sveučilišna naklada, Zagreb.

24. Opačić, V. T., Fijačko, P. (2017). Prostorni razvoj vikendaštva u ruralnim područjima Hrvatske: primjer Koprivničko-križevačke županije. Podravina: časopis za multidisciplinarna istraživanja, 16 (31), 97-116.

25. Opačić, V. T., Mikačić, V. (2009). Second home phenomenon and tourism in the Croatian littoral - two pretenders for the same space? Tourism: an international interdisciplinary journal, 57 (2), 155-175.

26. Pančić Kombol, T. (2006). Kulturno naslijeđe i turizam. Radovi Zavoda za znanstveni rad Varaždin, 16-17, 211-226.

27. Pigram, J., Jenkins, J. (1999). Outdoor recreation management, Routledge, London.

28. Poni y, L. (2010). Recreational area trends in rural-urban fringe: case study of Kórnik Gmina (commune), Tourism, 20 (2), 55-60.

29. State Geodetic Administration (2005). Central registry of spatial units in the Republic of Croatia. Zagreb.

30. State Geodetic Administration (2015). Digital model of relief of the Republic of Croatia. http://geoportal.dgu.hrl, Zagreb (November $5^{\text {th }} 2017$ )

31. Williams, A. M., King, R., Warnes, T. (2004). British second homes in Southern Europe: shifting nodes in the scapes and flows of migration and tourism. In: Tourism, mobility and second homes: between elite landscape and common ground (eds. Hall, C. M., Müller, D. K.). Channel View Publications, Clevedon, 97-112. 